\title{
Effectiveness of Range of Motion (ROM) Fingers and Spherical grip to Extremity Strength in Non Hemorrhagic Stroke Patients
}

\author{
Shindi Hapsari*, Sonhaji, Nindya Nurulia \\ Karya Husada Health and Science College of Semarang, Central Java, Indonesia \\ *shindihapsari@yahoo.com
}

\begin{abstract}
Clinical signs of loss of motor movement strength from impaired brain vascular disorders in non-hemorrhagic strokes such as darkness that occurs on one side of the body, patients need appropriate and rapid rehabilitation measures such as motion exercises. The purpose of this study is to find out the effectiveness of Range Of Motion (ROM) fingers and spherical grip on extremity strength in non-hemorrhagic stroke patients at K.R.M.T Wongsonegoro Hospital Semarang. This research is an experimental study with the design of the control group. The sampling technique is purposive sampling. The study's population was 32 . The intervention group $(n=16)$ respondents were given ROM therapy exercises of fingers and spherical grip, control group $(\mathrm{n}=16)$ respondents by giving ROM therapy exercise fingers. Exercise is done 2 times a day and done in 3 days for 15-20 minutes each time. Data analysis using Shapiro-Wilk, dependent paired t-test, and independent t-test. Statistical analysis results obtained by the intervention group (Range Of Motion therapy exercises (ROM) of the fingers of the hand and spherical grip exerted a more effective influence compared to the administration of therapy on the control group (ROM) of the fingers of the hand) get an average difference in extremity muscle strength with a p-value of 0.000 . The administration of spherical grip and Range Of Motion (ROM) therapy of the fingers of the hands is effective against increased extremity strength in non-hemorrhagic stroke patients
\end{abstract}

Keywords: Spherical Grip, Range of Motion (ROM) Fingers, Extremity Strength, NonHemorrhagic Stroke 


\section{STRADA Jurnal Ilmiah Kesehatan}

DOI: $10.30994 /$ sjik.v9i2.509

ISSN: 2252-3847 (print); 2614-350X (online)

Vol.9 No.2 November 2020 Page. 1650-1656

\section{BACKGROUND}

Stroke is a neurological disorder that occurs due to impaired blood circulation to the brain. Clinical symptoms occur suddenly and quickly resulting in acute brain damage and local/global.(Gillen, 2015) Stroke sufferers have a motor disorder in the brain, causing muscle atrophy. Muscle stiffness causes limited limbs in stroke sufferers.(Kusuma \& Sara, 2020) Sudden attacks require stroke patients to get Range of Motion cylindrical grip rehabilitation therapy where the exercise serves to improve musculoskeletal function and assess strength with cylindrical objects. (Irawati et al., 2017)(Anggraini et al., 2018)

World Stroke Organization data shows that 13.7 million new cases of stroke each year and 5.5 million deaths occur from stroke disease. About $70 \%$ of stroke diseases and $87 \%$ of deaths and disabilities from stroke occur in low- and middle-income countries. Stroke as part of cardiovascular disease is classified into catastrophic disease because it has a wide economic and social impact. This stroke causes permanent disability which can certainly affect the productivity of the sufferer. Nationally, the prevalence of stroke in Indonesia based on the age of $>15$ years is $10.9 \%$ or an estimated 2,120,363 people. (KEMENTERIAN KESEHATAN REPUBLIK INDONESIA, 2018)

High cases of stroke prevalence in Indonesia, rehabilitation is seen as important in treatment interventions in stroke patients. In non-hemorrhagic stroke patients after an attack resulting in sensory and motor impairment, including balance disorders, muscle weakness, and motor control disorders resulting in loss of coordination in the body(Nurtanti \& Ningrum, 2019). ROM is a rehabilitation exercise that can be given to non-hemorrhagic stroke patients that aim to maintain and improve the level of ability to move joints (Kusuma \& Sara, 2020) .

Movement on the hands can be stimulated with the practice of grasping functions that are through three stages, namely opening the hands, close the fingers to grasp the objects and regulate grip power. (Mariyanto \& Herisanti, 2019)

There is a problem that occurs in stroke patients, in this case, researchers provide interventions that are expected to benefit stroke patients with Range of Motion exercises and spherical grip on the strength of the extremities in non-hemorrhagic stroke patients at K.R.M.T Wongsonegoro Hospital Semarang.

\section{METHODS}

This study used a quasi-experiment research design with a pre-post test design using a control group. The sampling technique used is the total sampling and the number of samples as many as 32 respondents. Normality test data used Shapiro-Wilk and influence test using paired t-test and for effectiveness test using independent $t$-test. The sampling technique uses purposive sampling techniques where the samples in this study are non-hemorrhagic stroke patients who have muscle strength of 1-3, then divided into two groups, namely the intervention group and the control group. The intervention group was 16 respondents and a control group of 16 respondents. Exercise is done 2 times a day and done in 3 consecutive days.

\section{RESULT}

In this study, the number of respondents was 32, with 16 respondents in the intervention group, and respondents in the control group. the results of the researchers are spelled out in each table 


\section{STRADA Jurnal Ilmiah Kesehatan}

DOI: $10.30994 /$ sjik.v9i2.509

ISSN: 2252-3847 (print); 2614-350X (online)

Vol.9 No.2 November 2020 Page. 1650-1656

Table 1. Description of Respondent Characterist

\begin{tabular}{ccc}
\hline Category & Frequency & Presented (\%) \\
\hline Age & 3 & \\
\hline $45-50$ & 5 & 15.6 \\
$51-55$ & 10 & 31.2 \\
$56-60$ & 9 & 28.1 \\
$61-65$ & 3 & 9.4 \\
$66-70$ & 2 & 6.2 \\
$71-75$ & 32 & 100.0 \\
Total & & \\
Gender & 13 & 40.6 \\
Male & 19 & 59.4 \\
Female & 32 & 100.0 \\
Total & & \\
\hline Weakness of the & & 50.0 \\
extremities & 16 & 50.0 \\
Right & 16 & 100.0 \\
Left & 32 & \\
Total & &
\end{tabular}

Based on table 1 it can be known that the number of respondents in this study as many as 32 respondents. Based on the age status of the respondents in this study, the most vulnerable were 56-60 years old as many as 10 respondents $(31.2 \%)$, for ages $45-50$ as much as 3 respondents $(9.4 \%)$, for ages $51-55$ as much as 5 respondents (15.6\%), for ages 61-65 as much as 9 respondents $(28.1 \%)$, and ages $65-70$ as much as 3 respondents $(9.4 \%)$, and for ages $71-75$ as many as 2 respondents $(6.2 \%)$. The characteristics of respondents based on gender in non-hemorrhagic stroke patients for the male gender were 13 respondents $(40.6 \%)$, and for women, as many as 19 respondents (59.4\%), and the characteristics of weakness experienced by non-hemorrhagic stroke patients were found to be the result between right extremity disorder and left extremity which is the same, for the right extremity as much as 16 weakness of the right extremity sufferer $(50 \%)$ and 16 sufferers of leftist weakness $(50 \%)$.

Table 2. Frequency distribution of the strength of the extremities of non-hemorrhagic stroke patients before and after therapy was carried out in the intervention group

\begin{tabular}{lllll}
\hline Variabel & N & Mean & Min & Max \\
\hline Pre test intervensi & 16 & 17.019 & 2.2 & 27.0 \\
Post test intervensi & 16 & 17.437 & 2.4 & 27.6 \\
\hline
\end{tabular}

Based on Table 2 indicates that the frequency distribution of extremity strength before the range of motion (ROM) therapy of the fingers with spherical grip therapy in the intervention group that the average extremity strength before being given therapy amounted to 17,019 , While the lowest extremity strength score was 2.2 and the highest extremity strength score was 27.0 , and after being given the average extremity strength therapy in the intervention group of 17,437 , the lowest extremity strength score was 2.4 and the highest extremity strength score was 27.6 


\section{STRADA Jurnal Ilmiah Kesehatan}

DOI: $10.30994 /$ sjik.v9i2.509

ISSN: 2252-3847 (print); 2614-350X (online)

Vol.9 No.2 November 2020 Page. 1650-1656

Table 3. Frequency distribution of the strength of the extremities of non-hemorrhagic stroke patients before and after therapy was performed in the control group

\begin{tabular}{lllll}
\hline Variabel & N & Mean & Min & Max \\
\hline Pre test control & 16 & 12.019 & 3.2 & 20.3 \\
Post test control & 16 & 12.125 & 3.2 & 20.4 \\
\hline
\end{tabular}

Based on Table 3, indicates that the frequency distribution of extremity strength before the range of motion (ROM) therapy was performed by the fingers in the control group that the average extremity strength before being administered therapy was 12,019 , while the lowest extremity strength score was 3.2 and the highest extremity strength score was 20.3, and after being administered the average extremity strength therapy in the control group was 12,125 . The lowest extremity strength value is 3.2 and the highest extremity strength value is 20.4 .

Table 4. Independent t-test in the intervention and control group after therapy

\begin{tabular}{|c|c|c|c|}
\hline & & $\begin{array}{l}\text { Levene's test for } \\
\text { equality variances }\end{array}$ & $\begin{array}{c}\text { t-test for equality } \\
\text { means }\end{array}$ \\
\hline \multirow{2}{*}{$\begin{array}{l}\text { Post test intervention group } \\
\text { and control group }\end{array}$} & $\mathrm{N}$ & Sig. & Sig. 2 tailed \\
\hline & 32 & 0.102 & 0.034 \\
\hline
\end{tabular}

Based on Table 4 shows that there are differences in the effectiveness of extremity forces in intervention groups and control groups as evidenced by sig values. (2-tailed) $0.034<0.05$, it can be concluded $\mathrm{Ha}$ is accepted and $\mathrm{H} 0$ is rejected which means there is an average difference between the effectiveness of strength in the intervention group and the control group in non-hemorrhagic stroke patients at K.R.M.T Wongsonegoro Hospital Semarang.

Tabel 5. Effectiveness of administering therapy in interventional groups and control groups

\begin{tabular}{ccccc}
\hline Variabel & & $\mathrm{N}$ & Mean & $\mathrm{p}$-value \\
\hline & Before & 16 & 17.019 & \\
Intervensi & After & 16 & 17.437 & 0.000 \\
Control & Before & 16 & 12.019 & \\
\cline { 5 - 6 } & After & 16 & 12.125 & 0.000 \\
\hline
\end{tabular}

Based on Table 5, showed that there were differences in the effectiveness of extremity strength in the intervention group and the control group as evidenced by the p-value $\neg 0.000<0.05$ of this table also found differences in the average value of extremity strength between the intervention and control groups, where the intervention group had a difference in extremity strength before and after the administration of therapy of 0.418 and in the control group before and after the administration of therapy of 0.106 . Based on the average difference in therapeutic administration given to non-hemorrhagic stroke patients for the two groups, the administration of range of motion (ROM) exercises with spherical grip (intervention group) was more effective at increasing extremity strength for non- 


\section{STRADA Jurnal Ilmiah Kesehatan}

DOI: $10.30994 /$ sjik.v9i2.509

ISSN: 2252-3847 (print); 2614-350X (online)

Vol.9 No.2 November 2020 Page. 1650-1656

hemorrhagic stroke patients than giving range of motion (ROM) exercises to the fingers (control group).

\section{DISCUSSION}

In the results of the study, the increase in extremity strength with the mean value rising to 0.313 proved that the administration of ROMs with spherical grip exercises by grasping spiked balls is more effective in increasing the value of extremity strength. Range Of Motion (ROM) exercises of the fingers with Sphericalgrip can cause stimulation, thus increasing stimulation in the nerves of the extremity muscles, therefore by training the Range Of Motion (ROM) of the fingers with Sphericalgrip regularly with the correct steps i.e. by moving the joints and muscles, then the strength of the extremities will increase.(Sukmaningrum et al., 2012)(Olviani et al., 2017) Movement exercises, especially the range of motion for non-hemorrhagic stroke patients, can increase the patient's independence (SRI, 2019), with exercises in motion, muscles also prevent muscle stiffness, promote blood circulation, and increase muscle life and minimize physical defects so that they can undergo normal activity.(Anggraini et al., 2018; Sofiana, 2018) This is done regularly so the muscle tolerance to perform movement increases (Nurtanti \& Ningrum, 2019; SRI, 2019).(Mardati et al., 2014; Olviani et al., 2017; Sukmaningrum et al., 2012)

The results showed that range of motion therapy exercises (ROMs) with spherical grips was more effective at increasing extremity strength in non-hemorrhagic stroke patients compared to Range Of Motion (ROM) therapy exercises of the fingers as evidenced by sig values. (2-tailed) $0.034<0.05$, it can be concluded Ha is accepted, and H0 is rejected which means there is an average difference between the effectiveness of strength in the intervention group and the control group in non-hemorrhagic stroke patients at K.R.M.T Wongsonegoro Hospital Semarang. The theory states that the range of motion (ROM) exercises of the fingers with spherical grip is a functional exercise of the hand by grasping an object shaped round like a rubber ball on the palm of the hand. Movement on the hands can be stimulated by the practice of grasping functions performed through three stages, namely, opening hands, closing fingers to grasp objects, and adjusting the grip strength.(SRI, 2019; Sukmaningrum et al., 2012) This is in combination with the theory of Newton III's Law which explains the same style of action as the reaction style, which can be applied to respondents who exercise using heavier objects will result in greater and maximum effort than just range of motion therapy exercises of the fingers alone. when the training respondents used rubber balls, the resulting power was greater and the contractions that occurred were stronger resulting in an increase in the motor unit to produce acetylcholine, resulting in contraction (Olviani et al., 2017) Mechanisms through more impact on improved muscle strength (Mardati et al., 2014; Sukmaningrum et al., 2012)

Range Of Motion (ROM) training is an exercise that aims to reduce contractions and provide joint flexibility in extremities who have suffered a stroke.(Kusuma \& Sara, 2020) The administration of a range of motion (ROM) of the fingers and spherical grip is proven in improving the value of extremity strength function in non-hemorrhagic stroke patients (Mardati et al., 2014). Based on the results of the study in the intervention group who had been given exercise therapy Range Of Motion (ROM) fingers with spherical grip in getting an average extremity strength was 17,437 and in the control group that had been given Range Of Motion therapy (ROM) the fingers in the average extremity strength was 12,125. Judging by the results of the study after being given therapy in the control group and the intervention group both experienced muscle strength in respondents. It can be concluded that with exercise therapy Range Of Motion (ROM) fingers with Sphericalgrip therapy (intervention 


\section{STRADA Jurnal Ilmiah Kesehatan}

DOI: $10.30994 /$ sjik.v9i2.509

ISSN: 2252-3847 (print); 2614-350X (online)

Vol.9 No.2 November 2020 Page. 1650-1656

group) there is a significant difference in strength compared to just giving exercise therapy Range Of Motion (ROM) fingers only in non-hemorrhagic stroke patients(Mariyanto \& Herisanti, 2019; Sofiana, 2018)

According to the results of the study obtained by researchers, there was an increase in extremity strength in non-hemorrhagic stroke patients after being given range of motion (ROM) exercise therapy with spherical grip therapy twice a day conducted in the morning and evening in 15 minutes for 3 consecutive days. The above opinion is supported that the mechanism of motor neutrons can increase smooth muscles in the extremities. Active Assistive Range Of Motion (ROM) exercises can cause stimulation, which can increase muscle tone(Olviani et al., 2017; Sukmaningrum et al., 2012).

\section{CONCLUSION}

The administration of exercise therapy in the intervention group (Range Of Motion (ROM) therapy exercises of the fingers and spherical grip exerts a more effective influence compared to the administration of therapy in the control group (ROM) of the fingers of the hand) get an average difference in extremity muscle strength with a p-value of 0.000 . From the results of this study, it is expected that the next study can conduct research by using or adding other variables with better research design by maintaining the characteristics of the respondents, more attention to the Operational Standard procedure (SOP) flow policy from the Hospital in the rehabilitation process, and pay more attention to the homogeneity of respondents to be taken for the research sample, and further research can apply other ROM movements that further accelerate restoring the part that is experiencing weakness (hemiparesis).

\section{REFERENCES}

Anggraini, G. D., Septiyanti, S., \& Dahrizal, D. (2018). Range Of Motion (ROM) Spherical Grip dapat Meningkatkan Kekuatan Otot Ekstremitas Atas Pasien Stroke. Jurnal Ilmu Dan Teknologi Kesehatan, 6(1), 38-48.

Gillen, G. (2015). Stroke rehabilitation: a function-based approach. Elsevier Health Sciences.

Irawati, P., Sekarsari, R., \& Marsita, A. (2017). EFEKTIFITAS LATIHAN RANGE OF MOTION CYLINDRICAL GRIP TERHADAP PENINGKATAN KEKUATAN OTOT EKSTREMITAS ATAS PADA PASIEN STROKE NON HEMORAGIK DI RUANG RAWAT INAP RSU KABUPATEN TANGERANG. Jurnal JKFT, 1(2), $18-31$.

KEMENTERIAN KESEHATAN REPUBLIK INDONESIA. (2018). No Title. https://pusdatin.kemkes.go.id/folder/view/01/structure-publikasi-data-pusat-data-daninformasi.html

Kusuma, A. S., \& Sara, O. (2020). Penerapan Prosedur Latihan Range Of Motion (ROM) Pasif Sedini Mungkin pada Pasien Stroke Non Hemoragik (SNH). Syntax Literate; Jurnal Ilmiah Indonesia, 5(10), 1015-1021.

Mardati, L., Setyawan, D., \& Kusuma, M. A. B. (2014). Perbedaan Range of motion spherical grip dan cylindrical grip terhadap kekuatan otot ekstremitas atas pada pasien stroke di RSUD Tugurejo Semarang. Karya Ilmiah.

Mariyanto, Q., \& Herisanti, W. (2019). The Effect Of Combination Spherical Grip And Kinesio Taping Exercise To Enhance Of Muscle Strength In Ischemic Stroke Patients In Jemursari Islamic Hospital Surabaya. Jurnal Ners Dan Kebidanan Indonesia, 6(2), 113-123. 


\section{STRADA Jurnal Ilmiah Kesehatan}

DOI: $10.30994 /$ sjik.v9i2.509

ISSN: 2252-3847 (print); 2614-350X (online)

Vol.9 No.2 November 2020 Page. 1650-1656

Nurtanti, S., \& Ningrum, W. (2019). EFEKTIFITAS RANGE OF MOTION (ROM) AKTIF TERHADAP PENINGKATAN KEKUATAN OTOT PADA PENDERITA STROKE. Jurnal KEPERAWATAN GSH, 7(1), 14-18.

Olviani, Y., Mahdalena, M., \& Rahmawati, I. (2017). PENGARUH LATIHAN RANGE OF MOTION (ROM) AKTIF-ASISTIF (SPHERICAL GRIP) TERHADAP PENINGKATAN KEKUATAN OTOT EKSTREMITAS ATASPADA PASIEN STROKE DI RUANG RAWAT INAP PENYAKIT SYARAF (SERUNI) RSUD ULIN BANJARMASIN. DINAMIKA KESEHATAN: JURNAL KEBIDANAN DAN KEPERAWATAN, 8(1), 250-257.

Sofiana, N. (2018). APLIKASI RANGE OF MOTION AKTIF-ASISTIF (SPHERICAL GRIP) UNTUK MENINGKATKAN KEKUATAN OTOT EKSTREMITAS ATAS PADA PASIEN STROKE NON HEMORAGIK DI RUMAH SAKIT ROEMANI MUHAMMADIYAH SEMARANG. Universitas Muhammadiyah Semarang.

SRI, A. W. (2019). PENERAPAN TERAPI ROM AKTIF ASISTIF: SPHERICAL GRIP PADA PASIEN STROKE NON HEMORAGIK UNTUK PEMENUHAN KEBUTUHAN MOBILITAS FISIK DI INSTALASI GAWAT DARURAT RSUD dr. SOEDIRMAN KEBUMEN. STIKES MUHAMMADIYAH GOMBONG.

Sukmaningrum, F., Kristiyawati, S. P., \& Solechan, A. (2012). Efektivitas Range Of Motion (Rom) Aktif-Asistif: Spherical Grip Terhadap Peningkatan Kekuatan Otot Ekstremitas Atas Pada Pasien Stroke Di Rsud Tugurejo Semarang. Karya Ilmiah. 